\title{
Management of Education Resource Centre and Capacity Development in Nigerian Universities
}

\author{
Comfort Ayandoja Akinfolarin \\ Department of Educational Management, Faculty of Education, Adekunle Ajasin University, Akungba-Akoko, \\ Nigeria \\ Email: ajoro123@yahoo.com
}

Received 29 March 2016; accepted 29 August 2016; published 1 September 2016

Copyright @ 2016 by author and Scientific Research Publishing Inc.

This work is licensed under the Creative Commons Attribution International License (CC BY). http://creativecommons.org/licenses/by/4.0/

(c) (7) Open Access

\section{Abstract}

Education centre is a capacity development infrastructure which could be formally or informally set up to develop potentials of individuals at a specified period. This paper therefore examined the level of work ethics and the challenges that are faced by women in the utilization of the educational resources which depend largely on the total commitment of the university leadership to the effective application of the management principles in the articulation of programmes, provision of facilities, networking with relevant stakeholders and agencies in promoting quality values and best practices in implementation of policies and programmes for the advancement in knowledge, skill acquisition and value oriented services delivery that had been vigorously pursued at the Women Studies and Development Center (WSDC) at Adekunle Ajasin University, Akungba Akoko, Ondo State, Nigeria. The study adapted the descriptive survey research design. The respondents were purposively selected and the sample consisted of 99 office assistants engaged in the existing five (5) faculties, administrative departments and units within the university. Data were collected using questionnaire tagged “Organization Work Ethics Questionnaire” (OWEQ). Two research questions were formulated and data were analyzed using percentage and mean score. The results showed that the performance of office assistants was at the average level with the use of technological gadgets and the work ethics was fairly effective. The study concluded that the university management should expand working facilities and capacity advancement programme to improve the work ethics for optimal efficiency.

\section{Keywords}

Centre, Resource, Leader, Women Capacity 


\section{Introduction}

Education could be identified as a process of developing and making individual to be a useful citizen of a Society. This could be formally and/or informally imparted to an individual or set/group of people with similar interests and beliefs. The formal form of education is usually guided by aims and objectives, philosophy and curriculum that spell out the length or duration and age at which such education is acquired, efforts of the government or stakeholder, types of education, educational services, planning, administration and its supervision and the financial implication. This is well spelt out in the National Policy on Education [1] (FGN 2013). Within the formal education system, the informal education is introduced to support the formal training so as to help especially the disadvantaged adults. National Policy on Education (FGN 2013, Section 6, Mass Literacy, Adult and Non-formal Education) discusses this fully. Observations made within the formal education system are the involvement of resource persons sharing education support with the formal education. The activities of these resource persons are usually carried out in a centre where related or relevant issues concerning individual or group of people, both at national and international levels are shared and discussed with possible solutions proffered.

An Educational Centre, therefore, is a necessity in a society or community where additional knowledge, skills and practices are provided and acquired at one's leisure time. Institutions of learning, particularly universities have centres where researches, training and development of personnel within and outside the institutions are undertaken. It is of interest to note that there are differences in training, educating and development of staff in a centre. [2] Effah (1998) distinguished between the use of these terms: training, education and staff development thus:

- Training implies the development of specific skills to prepare individuals to carry out specific tasks effectively.

- Education is the development of a broad range of abilities, knowledge and skills of general application.

- Staff development involves a combination of training, education experience and variety of other means of increasing personal and indeed, group effectiveness.

Schermerhorn (1984) [3] categorized skills into two:

1) What is required to do a specific job?

2) What additional skills are needed over time?

Before a centre could be functional and effective in training and educating the individual, it is imperative to put in place what it takes to equip individual trainees with some of the basic skills required for the performance of their jobs. A critical look at the operation of the Women Studies and Development Centre (WSDC), Adekunle Ajasin University, Akungba Akoko shows the capacity and integrity of the top management in articulation of vision, mission, programmes, sustainable strategies, practical values and benefit to the people and the community at large.

This review is therefore carried out to share best practices at the Women Studies and Development Centres of Adekunle Ajasin University, Akungba Akoko, Ondo State, Nigeria.

Vision: Empower women and girl-child through developmental strategy to promote welfare in all ramifications.

Mission: To identify women and girl's-child constraints through training, consultancy services and research in order to develop valuable aspirations.

\section{Brief History of Adekunle Ajasin University, Akungba-Akoko}

Adekunle Ajasin University, Akungba-Akoko (AAUA), a $21^{\text {st }}$ Century University properly called, relocated from where it incepted as Ondo State University, Ado-Ekiti to Akungba-Akoko in November 5, 1999. In spite of teething challenges of accommodation, finance, man-power and other prevailing issues, the authorities (Ag. Vice Chancellor and his Management staff), were able to salvage the situation and steady up a befitting University with five (5) Faculties, viz: Arts, Education, Law, Sciences and Social \& Management Sciences) each with its specialized Departments. Within a spate of few years of its relocation, the University gained recognition due to the team spirit and dedication of reputable scholars from different disciplines such as educational administrators and managers, library scientists, banking and financial specialists, linguistics and a host of other professionals.

The University has to its credibility, academic support units that are attached to and service the faculties and departments in research, training and skills acquisition to Staff, Students, the Community, the State and the Na- 
tion at large. These include the University Library, Information and Communication Technology Application Centre (ICTAC), The Institute of Education, Institute of Part-Time Programmes, Centre for Diploma and PreDegree Studies, Centre for Entrepreneurship Development and General Studies Unit.

During the 2010 Session, four Development Centres were created to complement the University's academic programmes and the existing academic programmes. These are:

- Leadership Institute of Public Policy and sustainable Development (LIPPSDev).

- Women Studies and Development Centre WSDC.

- Ajasin Varsity Theatre (AVT).

- University Advancement Office (UAO).

The focus of this paper is on Women Studies and Development Centre (WSDC). The Governing Council of Adekunle Ajasin University through a decision extract of its $43^{\text {rd }}$ Regular Meeting, held on Friday $13^{\text {th }}$ August, 2010, received and considered the recommendation for the establishment of Women Studies and Development Centre in the University. Council paid attention to the fact that the Centre, when established, would focus on issues relating to women empowerment as well as focus on women and the situation of the girl-child.

It further stated that the Centre would focus on inter-disciplinary research and engagement of Women Studies. In support of the above, the Adekunle Ajasin University, Akungba-Akoko, under the leadership of the Vice Chancellor, Prof. N. O. Mimiko, promptly inaugurated the Centre on the $19^{\text {th }}$ October, 2010 with an average population of female staff members and students at the 2010/2011 session [4] (Consolidated Annual Report, 2010 \& 2011).

The first Acting Director of the Centre was Dr. Irene O. Adadevoh of blessed memory. She was of the Department of Philosophy. She served the Centre, in an acting capacity in the 2010-2011 Session. Dr. C. A. Akinfolarin, was appointed the next Acting Director for a period of two and a half years (August, 2011-February, 2014).

\section{Resource Expectations}

In organizational studies, resource management is the efficient and effective deployment of an organizational resource when they are needed. Such resources could be financial resources, inventory, human skills, production resources or informational technology (IT). Resources in an organization could be grouped under two major categories: Human and Non-human capacities or could be identified as 4 m's (men, money, machines and materials).

The human is the individual who has the skills, knowledge and ability to work with and through other people using every other gadget-manual or electronics, to achieve the organizational goals and objectives. Adekunle Ajasin University, Akungba-Akoko, WSDC from inception had it in her plan to have a Board that would oversee its activities.

As we can see in Figure 1, it is worth noting that most of the women related centres depend on Board of Trustees such as co-coordinating members, friends, agencies and donors for their financial and human supports. Examples are Women Research and Documentation Centre (WORDOC) of Institute of African Studies, University of Ibadan, Nigeria, Women Studies in Indian Universities and Colleges, Country Women Association of Nigeria (COWAN), Women's Health Research Network in Nigeria (WHERNIN) Ahmadu Bello University, Zaria.

As we can see in Figure 2, the WSDC operated her activities using capacity development model. Both academic and non-academic members serve as resource-based committee chaired by the Ag. Director of the Centre. It is the culture of AAUA to have a Professor as Directors of Centres but in the absence of a Professor, a Senior Lecturer or Reader is usually appointed as Acting Director who oversees all the activities of the Centre and is usually responsible to the Vice Chancellor.

The Committee deliberates on major issues and suggests workable strategies to the Vice Chancellor, who takes final decision before any programme is executed. Other important personnel of the Centre are the administrative staff members such as Clerical Officer, Research Assistants and Office Assistant who ensure that the offices and surroundings are kept tidy. Students are also brought on deck to contribute in various capacities.

Finance is the monetary aspect of the resources needed for the running of the centre. This is based on the need assessment of the centre. At the inception of the Centre, substantial amount was approved for the take-off, while other needs were being provided in the University budget. The running of the Centre was not solely based on 


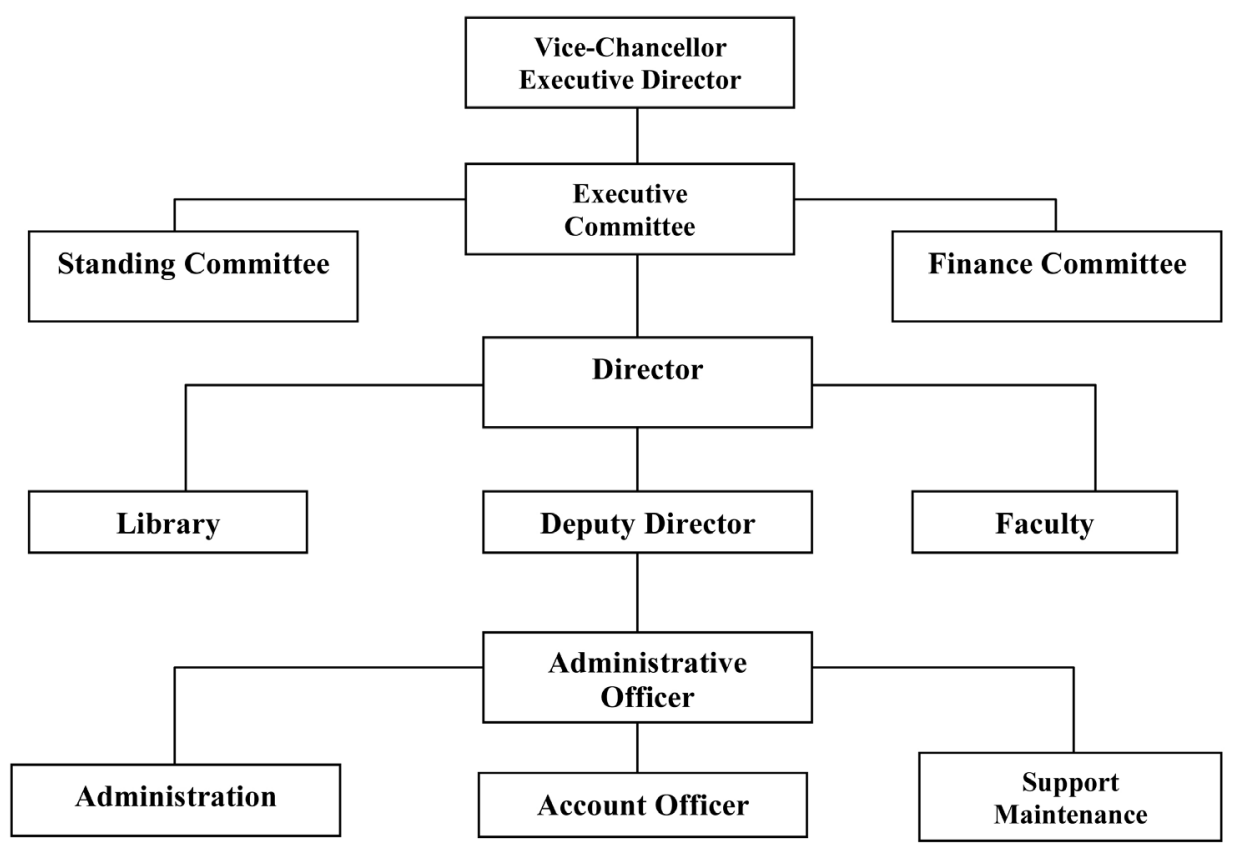

Figure 1. Organizational structure of WSDC, AAUA. Source: Prepared by the author.

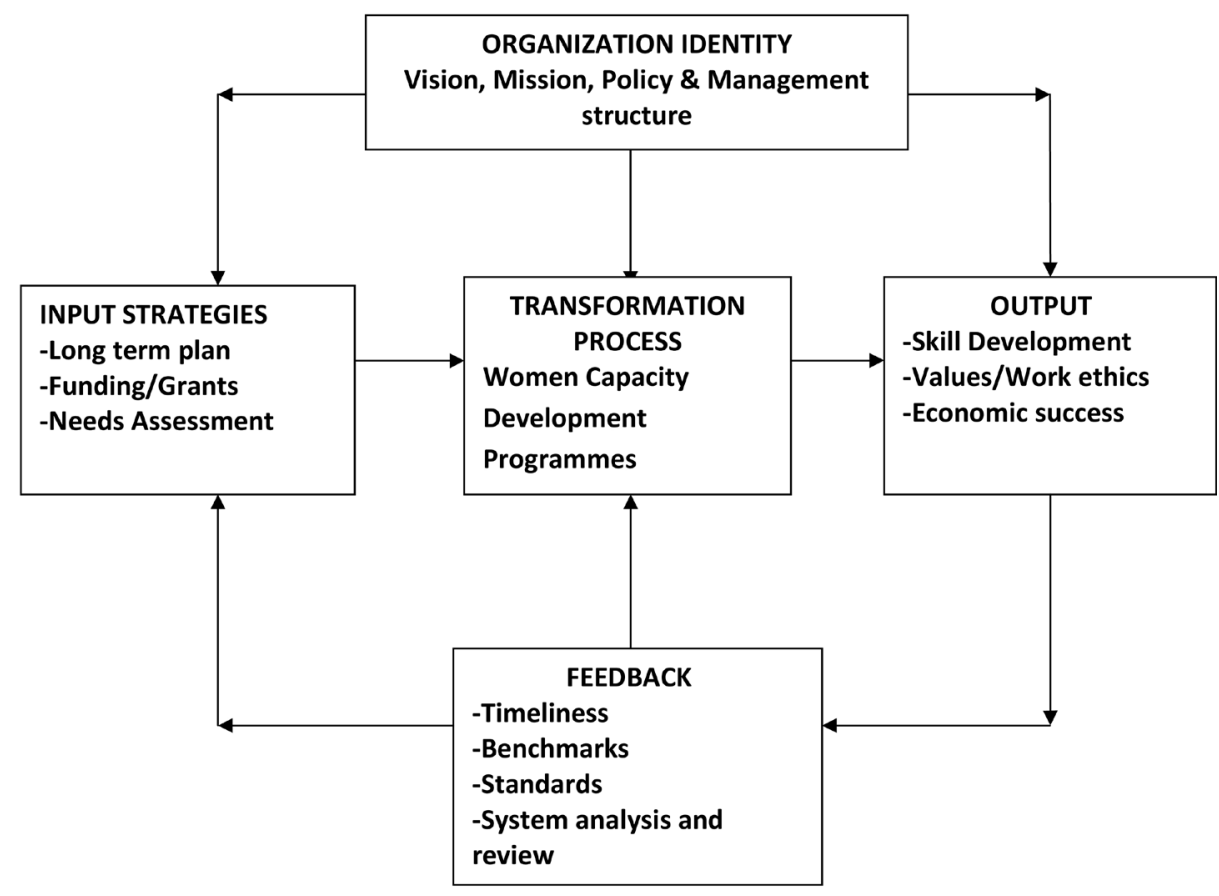

Figure 2. Model of women capacity development. Source: Prepared by the author.

financial support/empowerment. Most of the requests were processed through the University Central Stores where materials needed are quantified, through a requisition form and these materials are supplied while the monetary equivalent is treated at the Bursary from the allocated budget. Where the goods are not in the Central Stores, the Centre purchases these goods, audited all the receipts and goods and the money is reimbursed to the Centre from the allocated budget for the year. Each year, the Centre draws different proposed budget and the University approves through the Bursary from the subvention released from the Ondo State Government. Records of the financial disbursement are accurately kept. Salaries and wages form the crux of the financial 
need of the Centre. All the financial transactions are the cash needed to meet the instant requirements, payments for services and logistics.

Following the mission and vision of the Centre, Extension Services are part of the lineup of programmes to be executed. Women within Akungba and its environs and Ondo State at large are the target audience. Pupils and students of both genders are areas where the Centre proposes to extend her programmes. Proposal on Extension Services which regularly addresses the issues of Women Empowerment in Orientation Programmes are run by academic staff and experienced senior non-academic staff, are organized by WSDC in areas like violence against women, land ownership, and other social issues that are usually raised against women and young ladies. Common awareness activities such as abuse of media communication, musical conference, issues of memorable days, Science Training Workshops Exhibition, Self-Development Programme and others. This service has link with Non-Governmental Organizations (NGO) and international agencies like World Health Organization (WHO), United Nations International Children's Education Fund (UNICEF), United Nations Educational Scientific and Cultural Organization (UNESCO) and others.

\subsection{Monitoring and Review}

Leadership is commitment to excellence in all the programmes to ensure quality output in form of skill acquisition, work ethics and economic success. Also, accountability, check and balances are highly valued. The WSDC uses a quarterly Newsletter Publication to evaluate her programmes. Already publications on different organized programmes are in press. Internal Monitoring Evaluation Advisory Committee under the Chairmanship of the Vice Chancellor has been put in place. Other members of Committee are the Director and women within WSDC, State representative, National or State Women Commission Social Welfare/Advisory Board/Women and Child Development, a woman from each Local Government, a research NGO institute and a substantive Secretary to take the minutes.

\subsection{Leadership Expectation and Capacity Development}

Capacity is the ability of individuals, institutions and societies to perform functions, solve problems, set and achieve objectives in a sustainable manner. Capacity development is therefore the process through which the abilities and capabilities of the individual, team or entire workforce, to perform a given task is strengthened over time. It is a process of personal improvement for increased effectiveness on a given task. Every workplace, as we have in AAUA, expects that the individual worker, the system, process and the organization should work together and in harmony to improve the capacity of the individual worker to perform a given task and ultimately add up to the organization's aggregate performance (Mimiko 2012) [5].

[6] Thomas and John (1978) emphasized the importance of human resources as important to any organization, the human resources will need a shelter for protection and will also need material resources like technological gadgets both manual and electronically operated ones to be used in carrying out operations within the centre. To make these resources functional, all the $4 \mathrm{~ms}$ (man, money, materials and machines) are usually put to work by manager who sees to the organizational principles of planning, coordinating, organizing staffing and evaluating activities of the Centre.

In an organization where there are policy statements, rules and regulations guiding the operations, a seasoned educative and inspiring individual is needed to run its affairs effectively and efficiently. Such an individual is expected to have the knowledge, skills and methodology of working with people and other resources to achieve an ultimate goal.

Women Studies and Development Centre is expected to have a leader who has the strong charisma and could carry other people along, being able to assert herself, be aware and understands the gender patterns that is to be in a continuous process. [7] Dahlbom-Hall (2008) emphasized that for a leader, it is important to see both individual pattern and the general pattern. She further explained that there is not only one way to be a man or a woman. "You have to find your own best way to integrate gender awareness in your identity and in your leadership. You must learn to lead yourself before you can lead others. And to become a successful leader you must learn to deal with gender conflicts”. Many definitions of leadership were outlined by Gedney (1999) [8] but he concluded that leadership is "Action that focuses resources to create desirable opportunities. This definition is in line with this paper which focuses on resources and expectations of Leadership in WSDC.

To achieve the desirable goals within WSDC, the integrity of the leadership is predicted on the following four 
types of leadership styles/strategies:

- Thought leaders.

- Courageous leaders.

- Inspirational leaders.

- Servant leaders.

Thornton (2013) [9] was of the opinion that all leaders want to change the status quo, but they employ different approaches. He further stated that effective leaders believe that individuals, organizations and even nations possess undiscovered talents and untapped resources. They seek to unleash the full potentials of their followers so they could reach higher and go further than they previously thought possible. It could be noted that successful leaders come in different shapes and sizes. No two styles are alike and no single leadership style is always the best, some take the lead with their ideas, while others lead with their passion and conviction. Still others lead by demonstrating courage in the face of risks and the unknown, while some bring about change by serving others. Examples of such female leaders are Moremi of Ile-Ife, Funmilayo Ransome Kuti of Abeokuta, Queen Amina of Zauzau, Mother Teresa, Oprah Winfrey, to mention a few. It was believed that these intelligent leaders, "thought like a leader, did not wait to be told, took control and were celebrated”.

\subsection{Characteristics of Successful Leadership within Women Studies and Development Centre (WSDC)}

A visionary leader in Women Studies and Development Centre can function effectively by understanding and interpreting the vision and mission of the Centre [10] Akinfolarin (2013) posited thus:

Vision: To empower women and the girl child through progressive developmental strategy in a bid to build, strengthening and promoting their general welfare in all ramifications.

Mission: To identify the constraints of women and the girl child with a view to addressing them through high standard of training, consultancy services and research in order to develop a dignifying and equitable society in which the values and aspirations of women and girl the child can be fully realized.

The operation of the WSDC is anchored on the following leadership characteristics.

- Proactive and Reactive

The leadership is proactive and always thinking ahead, eager to master her operational environment with the aim of avoiding problems before they arise.

- Flexible and Adaptable

The leadership is dynamic and easily adapt to new surroundings and situations, doing her best to adjust to the demands of the new technology in the $21^{\text {st }}$ century. This has greatly helped the WSDC in exchanging information, ideas and entrepreneurial skills through the newsletters and official publications that are circulated within and outside the university community.

- Good Communicator

The leadership entertained issues, by being cautious to understand the needs and desires of others, considers all options and leads in the right direction.

- Respectful

At the WSDC, the clients are treated with high degree of respect and this has helped the centre to receive high level of patronage within and outside the university community.

- Enthusiastic

WSDC leadership is courageous, motivated and excited in dealing with issues and matters affecting women and the girl-child.

- Open Minded

The WSDC management considers all options when making decisions and evaluating the inputs from all interested parties and work for the betterment of the whole.

- Resourceful

The WSDC has been able to use the resources available judiciously and ask questions and create access to information for the benefit of the university community.

- Rewarding

The WSDC leadership recognizes the efforts of others and reinforce those actions.

- Well Educated 
A good leader must be well-informed, educated on policies, procedures, organizational norms and work ethics for quality service delivery.

- Open to Change

Innovative in all norms of the organization's activities, taking cognizance of all points of view and willing to change or adapt to qualitative policy, programme, standards and other relevant issues that come up.

- Interested in Feedback

It is the end that justifies the means. A good result at the end of any form of activities is usually the focus of the WSDC. The leadership works to have result for further developments.

- Evaluative

Evaluation of events and programmes is essential and given priority to improve and progress. Attention is paid to constant evaluation so as to improve and make changes on programmes and policies that are substandard.

- Organized

In preparation of any event; the leadership confidently get organized and carry people around her along so as to achieve the set goals.

- Consistent

The leadership is stable minded, attracts respect and confidence from the followers. Leaders show good examples by being consistent in discharging responsibilities.

- Delegator

The WSDC leadership makes a follow up and understands her follower's personality traits. The leader always makes use of the followers' talents to accomplish the organizational goals and objectives. McGregor (1960) [11] emphasized this in the theory $\mathrm{X}-\mathrm{Y}$ personality traits.

- Initiative

Leaders motivate their followers by planning and implementing new ideas, programmes, policies, events and other related activities that will boost the organization. [12] Ibukun (2004) emphasized that motivation are those things and situation that induced and sensitized individuals to perform and may be in form of incentives or sanctions. This is given high premium at WSDC.

Having looked at the characteristics of leadership at WSDC, other functions that will elevate and make leaders progressive in any organization are highlighted by [13] Simmons (2010) as follows:

- Help interpret the meaning of events.

- Create alignment on objectives and strategies.

- Build task commitment and optimism.

- Build mutual trust and cooperation.

- Strengthen collective identity.

- Organize and co-ordinate activities.

- Encourage and facilitate collective learning.

- Obtain necessary resources and support.

- Develop and empower people.

- Promote social justice and morality.

\subsection{Statement of the Problem}

The number of women that are engaged in the academic and non-academic responsibilities is increasing with the enlightenment and active participation of women in academic and administrative duties in the Nigerian higher institutions of learning. However, the women are also faced with domestic, economic, political, social and organizational challenges which impede their optimal performance in the workplace. The management at Adekunle Ajasin University, Akungba-Akoko, therefore, considered it necessary to establish Women Studies and Development Centre (WSDC) as tool to address the challenges facing women in order to improve their professional knowledge, skills and work ethics for greater efficiency in the performance of their duties in the university. This study therefore seeks to examine the prevailing work ethics, challenges and the effect of women capacity development programme at Adekunle Ajasin University, Akungba-Akoko.

\subsection{Research Questions}

The following research questions were formulated to guide the study. 
1) What is the level of work ethics among women in Adekunle Ajasin University, Akungba-Akoko?

2) What challenges are faced by women in the performance of their duties at Adekunle Ajasin University, Akungba-Akoko?

\section{Methodology}

The study adopted the descriptive survey research design. The respondents were purposively selected and the sample consisted of 99 office assistants that were engaged in the existing five (5) faculties/administrative departments and units within the university. Data was collected using questionnaire tagged "Organization Work Ethics Questionnaire” (OWEQ). The instrument consisted of 25 items covering key variables of work simplification, time management, body posture and dress code, safety and precautions and finally challenges of organization performance. The instrument was validated for both face and content validity by two experts in the Department of Educational Management and one expert in the Department of Guidance and Counseling. Data were analyzed using simple percent and mean score.

\section{Analysis of Results}

As Table 1 reveals, the respondents were made up of the entire office assistants in the five faculties in the university namely: Arts, Education, Law, Management and Social Sciences and finally Sciences. The numbers of respondents for each faculty were 17, 28, 12, 22 and 20 respectively making a total of 99 respondents. 27 (27\%) of these respondents have below school certificate, 45 (46\%) of the respondents have school certificate while 27 (27\%) have OND as qualifications. 41 (41\%) of these respondents have between 1 - 10 years of work experience while 58 (59\%) have work experience of 10 years and above.

Working in a university system provides for a sense of acceptability in a very conducive environment where dignity of labour, hard work and ability to enhance character are exhibited. As we can see in Table 2, the office

Table 1. Demographic information of the respondents.

\begin{tabular}{|c|c|c|c|c|c|c|c|c|c|c|}
\hline \multirow[t]{2}{*}{ Faculty } & \multicolumn{6}{|c|}{ Qualifications } & \multicolumn{4}{|c|}{ Working experience } \\
\hline & $\begin{array}{l}\text { Below school } \\
\text { certificate }\end{array}$ & $\%$ & $\begin{array}{c}\text { School } \\
\text { certificate }\end{array}$ & $\%$ & OND & $\%$ & 1 - 10 years & $\%$ & $\begin{array}{c}\text { Above } 10 \\
\text { years }\end{array}$ & $\%$ \\
\hline Arts & 5 & 5 & 7 & 7 & 5 & 5 & 7 & 7 & 10 & 10 \\
\hline Education & 6 & 6 & 12 & 13 & 10 & 10 & 10 & 10 & 18 & 19 \\
\hline Law & 3 & 3 & 7 & 7 & 2 & 2 & 9 & 9 & 3 & 3 \\
\hline $\begin{array}{l}\text { Social and } \\
\text { Management } \\
\text { Sciences }\end{array}$ & 8 & 8 & 10 & 10 & 4 & 4 & 8 & 8 & 14 & 14 \\
\hline Sciences & 5 & 5 & 9 & 9 & 6 & 6 & 7 & 7 & 13 & 13 \\
\hline Total & 27 & 27 & 45 & 46 & 27 & 27 & 41 & 41 & 58 & 59 \\
\hline
\end{tabular}

Source: Fieldwork 2015.

Table 2. Perception of office assistants on work ethics.

\begin{tabular}{ccccccccccc}
\hline S/N & Variables & $\begin{array}{c}\text { Highly } \\
\text { effective }\end{array}$ & $\mathbf{\%}$ & Effective & $\mathbf{\%}$ & $\begin{array}{c}\text { Fairly } \\
\text { effective }\end{array}$ & \% & $\begin{array}{c}\text { Not } \\
\text { effective }\end{array}$ & \% & $\mathbf{X}$ \\
\hline 1. & Work simplification & 39 & 40 & 32 & 32 & 28 & 28 & 0 & 0 & 3.11 \\
2. & Time management & 41 & 42 & 28 & 28 & 30 & 30 & 0 & 0 & 3.11 \\
3. & $\begin{array}{c}\text { Body posture and } \\
\text { dress code }\end{array}$ & 44 & 45 & 20 & 20 & 30 & 30 & 5 & 5 & 3.04 \\
4. & Safety precautions & 60 & 60 & 20 & 20 & 14 & 15 & 5 & 5 & 3.36 \\
5. & Cumulative mean & & & & & & & & 3.16 \\
\hline
\end{tabular}

Source: Fieldwork 2015. 
assistants at AAUA were found to exhibit work ethics using the variables of work simplification, time management, body posture and dress code, and safety precaution. On work simplification, a cumulative mean of 3.11 was recorded. Out of the 99 participants at the training workshop, 39 participants (40\%) were of the opinion that the work carried out was highly effective and simplified by the use of modern technological gadgets such as mop pail and moping sticks, sweeping brush hoover and other cleaning gadgets. 32 (32\%) agreed that work is effective while 28 (28\%) were of the opinion that the work carried out were fairly effective. No participant was of the opinion that the work done was not effective. This corroborated [14] Alimi (2012), who found that clear objectives of work simplification improves efficiency eliminates unnecessary work and reduce expenses. The finding of this study is also supported by [15] Kitaw and Belachew (2007) that productivity improves with intelligently developed work methods by elimination of waste of any kind in a process.

Time is inelastic, its usage and duration usually determines the success or achievement of a set goal and objective. The perception of AAUA office assistants indicated that 41 (42\%) participants agreed that work ethics was highly effective, while 28 (28\%) were of the opinion that work ethics was effective 30 (30\%) agreed that work ethics was fairly effective. No participant agreed that work ethics was not effective. This result corroborated [16] Akinfolarin (2015) who discovered that time utilization was significantly effective when it comes to any educational sector where goals and objectives could be realized. The finding of this study is further supported by [17] Remez (2014) that time management is important for personal and career success; it teaches one how to manage time effectively and make the most use of it. Time is a special resource that cannot be stored or saved for future use. Time not well used cannot be retrieved. He further stated that an individual becomes more productive using improved time management skills and tools, and can accomplish more with less effort and time.

Perception of office assistants on work ethics in AAUA on body posture and dress code revealed that 44 (45\%) were highly effective, 20 (20\%) were effective, 30 (30\%) were fairly effective $5(5 \%)$ were not effective. In the work of [18] Agrawal, Madankar and Jibhakate (2011), they observed and found that due to continuous kneeling posture, workers got fatigued frequently and musculoskeletal problems were identified thus reducing their effectiveness. Also, [19] Durant (2014) states the benefits of dress code as employee ease, visual uniformity and problem avoidance. Safety precautions enhance healthy living and portrays individual attitude to life and thus add value to living. Office assistants perceived safety precautions to be highly effective with 60 (60\%), 20 (20\%), perceived it to be effective $14(15 \%)$ had it fairly effective and 5 (5\%) were not effective at all. Total cumulative Mean was 3.16.

As shown in Table 3, domestic pressure in an organization like the university could be the ability to withstand or cope with individual challenges that are related to the home front. Perception of office assistants in AAUA on domestic pressure was high with $60(60 \%)$ while $30(30 \%)$ was of the opinion that domestic pressure was fair and $9(10 \%)$ felt that the domestic pressure was low. Therefore it could be inferred that due to high level of domestic pressure, economic pressure and administrative workload, the office assistant performance was observed to be at the average level with the use of technological gadget at workplace which reflected $50 \%$.

The economic pressure revealed 64 (65\%) which was high while 30 (30\%) was fair and 5 (5\%) was low with a total mean score of 2.60. The Administration workload showed that 67 (68\%) was high, 20 (20\%) was fair and $12(12 \%)$ was low. The mean score obtained was 2.56. Influence of technological gadgets was high with 49 (50\%) while 30 (30\%) was fair and 20 (20\%) was low. Political influence 20 (20\%) was high 10 (10\%) was fair

Table 3. Perception of office assistants on challenges of organization performance.

\begin{tabular}{ccccccccc}
\hline S/N & Variables & High & \% & Fair & \% & Low & \% & $\times$ \\
\hline 1. & Domestic pressure & 60 & 60 & 30 & 30 & 9 & 10 & 2.52 \\
2. & Economic pressure & 64 & 65 & 30 & 30 & 5 & 5 & 2.60 \\
3. & Administrative workload & 67 & 68 & 20 & 20 & 12 & 12 & 2.56 \\
4. & Influence of technological gadgets & 49 & 50 & 30 & 30 & 20 & 20 & 2.29 \\
5. & Political influence & 20 & 20 & 10 & 10 & 69 & 70 & 1.51 \\
& Cumulative mean & & & & & & & 2.30 \\
\hline
\end{tabular}

Source: Fieldwork 2015. 
and 69 (70\%) was low. Office assistants' perception on domestic pressure, economic pressure, administrative workload, influence of technological gadgets and political influence has a cumulative mean of 2.30. This finding could corroborate the characteristics of leadership by [13] Simmons (2010) which stated that leaders:

- Help interpret the meaning of events.

- Create alignment on objectives and strategies.

- Build task commitment and optimism.

- Build mutual trust and cooperation.

- Strengthen collective identity.

- Organize and co-ordinate activities.

- Encourage and facilitate collective learning.

- Obtain necessary resources and support.

- Develop and empower people.

- Promote social justice and morality.

A leader with the aforementioned characteristics will be able to reduce the domestic, economic pressures, management administrative workload and political influence of his subordinates like the office assistants.

\section{Conclusions}

Women Studies and Development Centre of Adekunle Ajasin University, Akungba Akoko has, since inception, been playing crucial roles in encouraging women and the girl-child to gear up and develop the potentials in them. It encourages all round development (socially, physically, emotionally, spiritually and mentally), in particular. It uses developmental strategy to build, strengthen and promote the work ethics in all ramifications. The centre identifies the constraints of women as it affects their domestic life, economic activities, administrative duties, technological and political influence. These challenges are addressed through high standard of training, consultancy services and research to develop a dignifying and result oriented in programmes in which the values and aspirations of women can be realized.

In practice, the centre acts as a motivating point for the promotion and consolidation of women studies through research, training, field and extension services and consultancy assistance. The centre does not only care for women in academics but also incorporates men and women in academics. It also co-opts men and women in other spheres of life. International days of women, families and girl-child were domesticated; roundtable discussions, workshops, conferences and seminars were ways of carrying out all the programmes.

\section{Recommendations}

The following recommendations are made for the improvement at the women studies and development centre.

1) A substantive and befitting building with different units should be provided for the centre. A standard building with offices, for official operations, conference halls for meetings, practical rooms inform of designated lecture rooms or workshop studios are required with all the necessary equipment or gadgets as the name or programme denote.

2) Vehicle for running the affairs of the Centre should be provided.

3) The University should expand the scope of women participation in all her programmes and activities to broaden the knowledge, skills, experience and exposure of women so as to enable them cope effectively with the myriads of organizational challenges for efficient job performance.

4) There should be a follow-up research to evaluate the impact of training given the participants on the work ethics, time management and productivity at work.

5) The office assistants should be made comfortable by providing all the necessary gadgets to facilitate their work and make them productive effective and efficiently. Also, training should be organized particularly on new skills and use of new gadgets.

6) Health facilities should be provided so as to reduce both economic and domestic pressures.

\section{References}

[1] Federal Republic of Nigeria (2013) National Policy on Education. NERDC Press.

[2] Effah, P. (1998) The Training and Development of Academic Librarians in Ghana. Library Management, 19, 37-41. 
http://dx.doi.org/10.1108/01435129810198611

[3] Schermerhorn Jr., J.R. (1984) Management for Productivity. 3rd Edition, John Wiley \& Sons, New York, 272.

[4] Consolidated Annual Report (2010 \& 2011) Adekunle Ajasin University, Akungba-Akoko, Ondo State, Nigeria. www.autocure.org

[5] Mimiko, N.O. (2012) Key Note Address on Training Workshop for Office Assistants and Attendants. A Publication Powered by Women Studies and Development Centre, Adekunle Ajasin University, Akungba-Akoko.

[6] Thomas, A. and John, C. (1978) Human Resource Management and Business Life Cycles: Some Preliminary Propositions.

[7] Dahlbom-Hall, B. (2008) Gender Awareness Necessary for Good Leadership. A Newsletter from Autocure. www.autocure.org

[8] Gedney, C.R. (1999) Leadership Effectiveness and Gender. Air Command and Staff College, Air University Maxwell, Air Force Base, Alabama.

[9] Thornton, P.B. (2013) Management Principles and Practices. 5th Edition.

[10] Akinfolarin, C.A. (2013) Speech Delivered on Training Workshop for Office Assistants and Attendants. A Publication Powered by Women Studies and Development Centre, Adekunle Ajasin University, Akungba-Akoko.

[11] McGregor, D. (1960) The Human Side of Enterprise. McGraw-Hill Book Co., New York.

[12] Ibukun, W.O. (2004) Educational Management Theory and Practice. NIEPA Printing Press.

[13] Simmons, B.L. (2010) Ten Most Important Leadership Functions. Reviewed in Gary Yukl’s Leadership in Organizations (Seventh Editions).

[14] Alimi, O.S. (2012) Work Simplification and Time Management. Training Workshop for Office Assistants and Attendants. A Publication Powered by Women Studies and Development Centre, Adekunle Ajasin University, AkungbaAkoko.

[15] Kitaw, D. and Belachew, T. (2007) Work Simplification for Productivity Improvement. African Journals Online (AJOL).

[16] Akinfolarin, C.A. (2015) The Relationship between Time Utilization in Vocational and Technical Education, and Students' Perceived Learning Outcome in Selected Colleges in Southwest Nigeria. International Journal of Educational Organization and Leadership, 22, 1-8. http://dx.doi.org/10.18848/2329-1656/CGP/v22i03/48504

[17] Remez, S. (2014) Importance of Time Management. http://www.successconsciousness.com

[18] Agrawal, D.N., Madankar, T.A. and Jibhakate, M.S. (2011) Study and Validation of Body Postures of Workers Working in Small Scale Industry.

[19] Durant, K. (2014) What Are the Benefits of Setting a Dress Code in the Workplace? 


\section{Appendix 1. Organization Work Ethics Questionnaire (OWEQ)}

Dear Ma,

Kindly supply the information as required below. The information provided will be used for academic purpose solely and treated with utmost confidentiality.

\section{SECTION A}

Demographic Information

Please tick as appropriate

Faculty-Arts $\square \quad$ Education $\square \quad$ Law $\square$

Qualification-Below school certificate

Work experience $\square \quad 1$ - 10 years

Social \& Management Sciences School certificate $\square$

Sciences

10 years and above

OND

\section{SECTION B}

Please tick as appropriate

\begin{tabular}{|c|c|c|c|c|c|}
\hline $\mathrm{S} / \mathrm{N}$ & Variables & $\begin{array}{c}\text { Highly } \\
\text { Effective }\end{array}$ & Effective & $\begin{array}{c}\text { Fairly } \\
\text { Effective }\end{array}$ & $\begin{array}{c}\text { Not } \\
\text { Effective }\end{array}$ \\
\hline
\end{tabular}

A.

\section{Work Simplification}

1. How does the management make the organization objectives clear to the supporting staff?

2. Does management prepare work schedule to guide and support staff effectively?

3. Does the management provide adequate and effective materials for job performance?

4. How effective does the management provide adequate incentive for job satisfaction?

5. Does the management effectively seek opinion of support staff in work review?

B.

\section{Time Management}

6. How effective does the management enforce compliance with official working hours?

7. Does the management allocate appropriate timeframe to work schedule effectively?

8. Does the management compare work done with working hours appropriately?

9. Does the management ward off time wasters during working hours?

10. How effective does the management provide facilities for staff convenience during working hours?

C. Body Posture and Dress Code

11. Does the management provide adequate chairs and tables for staff convenience effectively?

12. Is the office furniture good and effective for correct sitting posture?

13. How effective is the office furniture constructed to prevent health problems like arthritis and back pain?

14. How effective does the management maintain corporate dressing among the staff?

15. How effective does the management deal with the use of dress that may be offensive to other employees? 


\section{Continued}

D.

Safety Precautions

16. Does the management provide effective cleaning agents (chemicals \& fragrances) to remove dust, stains and dirt in the offices?

17. Does the management provide effective cleaning gadgets (soft bristled brush) to remove dirt and dust in the offices?

18. The management prohibits the use of harsh products in the offices

19. How effectively does the management provide instruction to guide people on the use of office equipment?

20. Does the management provide effective fire extinguishers in the offices?

$\mathbf{S} / \mathbf{N}$

Variables

High Fair Low

E. Challenges of organization performance

21. What is the level of pressure you face at the home front?

22. What is the level of economic pressure you face that affects work performance?

23. What is the level of administrative workload in your place of work?

24. To what extent do technological gadgets influence your work?

25. To what extent does political influence affect your work performance?

\section{Submit or recommend next manuscript to SCIRP and we will provide best service for you:}

Accepting pre-submission inquiries through Email, Facebook, LinkedIn, Twitter, etc. A wide selection of journals (inclusive of 9 subjects, more than 200 journals)

Providing 24-hour high-quality service

User-friendly online submission system

Fair and swift peer-review system

Efficient typesetting and proofreading procedure

Display of the result of downloads and visits, as well as the number of cited articles

Maximum dissemination of your research work

Submit your manuscript at: http://papersubmission.scirp.org/ 